\title{
Supplementation of pasture for growth
}

\author{
D. S. Kronfeld', W. L. Cooper', K. M. Crandell', L. A. Gay', R. M. Hoffman'1 J. L. Holland', J. A. Wilson', D. Sklan'² and P. \\ A. Harris ${ }^{3}$
}

'Virginia Polytechnic Institute and State University, Middleburg Agricultural Research and Extension Center, Middleburg, USA

${ }^{2}$ Faculty of Agriculture, Hebrew University, Rehovot, Israel

3Waltham Centre for Equine Nutrition and Care, Melton Mowbray, England, UK

\begin{abstract}
Summary
Our goal was to design an optimal supplement for temperate, improved pastures. Nutrients in need of supplementation were identified by forage analysis and by comparing the nutritional status of foals and weanlings fed various forages and supplements. Forage analysis in a survey of 12 farms indicated that $P, Z n$, $\mathrm{Cu}$ and Se were often deficient. Serum analysis confirmed lower $\mathrm{P}$ and Se status in weanlings, and lower $\mathrm{Zn}$ status during weaning, in horses fed pasture and hay only, compared to those supplemented with $\mathrm{P}, \mathrm{Se}$ and $\mathrm{Zn}$. Serum retinol concentration and a relative dose response test revealed seasonal depletion of vitamin A in weanlings. Seasonal variations in hydrolysable and fermentable carbohydrates were compensated for by a supplement abundant in fat and fiber as well as vitamin A at twice the National Research Council's requirement, and minerals in amounts estimated statistically to reach optimal ranges.
\end{abstract}

keywords: $\quad$ pasture, supplement, minerals, vitamin A, fiber complete

\section{Ergänzungsfutter für Fohlen auf der Weide}

Wir versuchten, einen Plan zur optimalen Nährstoffversorgung von Pferden auf Kulturweiden zu entwickeln. Nährstoffe, deren Ergänzung notwendig ist, wurden durch Futteranalysen bestimmt und mit dem Versorgungsgrad von Fohlen und Absetzern verglichen, die mit verschiedenen Futtermitteln und Ergänzungen ernährt wurden. Futteranalysen von 12 Farmen zeigten, daß Phosphor, Zink, Kupfer und Selen oft defizient waren. Serum-Analysen bestätigten, daß bei Absetzern, die nur Gras oder Heu erhielten, eine marginale Versorgung für Phosphor und Selen und während des Absetzens auch für Zink vorlag im Vergleich zu Fohlen, die mit Phosphor, Selen und Zink supplementiert wurden. Bei Absetzern wurde durch Messung der Serum-Retinol-Spiegel sowie durch einen Response-Test auch eine saisonale Unterversorgung mit Vitamin A nachgewiesen. Um saisonal verminderte Gehalte an verschiedenen, leicht abbaubaren Kohlenhydraten auszugleichen, wurde ein fett- und faserreiches sowie mit Vitamin A angereichertes (doppelte Menge der NRC-Empfehlungen) Supplement mit zusätzlich adäquaten Mineralstoffmengen konzpiert.

Schlüsselwörter: Weidesupplement, Mineralien, Vitamin A, Rohfaser

\section{Introduction}

Pastures may provide nutrition less than optimal for growth of horses. The goal of these studies was to design an optimal nutritional supplement for growth and reproduction of horses kept on improved grass-legume pastures such as those found in central and northcentral Virginia. Specific objectives were to determine nutrients in need of supplementation by forage analysis and by comparison of nutrient status of foals and weanlings fed different diets and supplements, and to decide on the best delivery system for supplementary nutrients.

This research was prompted by a change in the mission of The Middleburg Agricultural Research and Extension Center (The MARE Center), a 160 ha farm in northcentral Virginia used for the study of forage systems for livestock, from beef cattle to horses. Our first step was to develop 50 ha into four, new, uniform bluegrass-white clover paddocks. The uniformity would allow us to argue that the horse is the statistical unit rather the paddock. Another 70 ha remained in mixed grass-legume swards of long standing, some predominently tall fescue, others predominently orchard grass, with red clover and alfalfa serving as legumes. In general, pastures were managed to maintain legumes as 10 to $40 \%$ of the area. The conversion from beef cattle to horses took two years, 1989-91, with the removal of endophyte infected tall fescue being especially difficult. Fifty Thoroughbred mares and two stallions were donated in 1990-91. Before The MARE Center was ready for equine experiments, we began a nutritional survey of Thoroughbred farms in central and northcentral Virginia.

\section{Nutritional survey and forage analysis}

This observational study aimed to evaluate the nutrition of Thoroughbreds in relation to growth and reproduction, with special attention to developmental orthopedic disease (DOD) and early embryonic loss. In the event, nothing new was found about $\mathrm{DOD}$ and nothing at all about reproductive efficiency. The most useful information was obtained by forage analysis.

Both pastures and hays were sampled on 12 farms, and 33 samples were submitted to the university's Forage Analysis Laboratory and Soil Analysis Laboratory. The botanical composition of these samples was similar to the MARE Center's pastures.

The forage laboratory applies official methods for the Dairy Herd Improvement Association (DHIA) to a nutrient profile regarded as suitable for dairy cows, and this situation is common throughout the USA. The dairy profile lacks much nutritional information needed for horses, so a horse profile was developed from available methods. The dairy profile routinely has only acid-detergent fiber (ADF) among fiber assays, but neutral-detergent fiber (NDF) was requested so that hemicellulose could be estimated by difference 
(NDF-ADF). This differentiation among fibers is important because hemicellulose (NDF-ADF) has a digestible energy about 8 to 12 $\mathrm{kJ} / \mathrm{g}$, compared to $5-9 \mathrm{~kJ} / \mathrm{g}$ for cellulose, lignocellulose and lignin (ADF), as inferred from Pagan (1994).

Virginia Tech's DHIA Laboratory does not routinely measure ether extract or ash, so no estimate of non-structural carbohydrates (NSC) was available. In general in the USA, assays for soluble fibers (gums, mucilages and pectins), starches (hydrolysable or resistant to amylolytic hydrolysis) and sugars are not available from forage analysis laboratories. The MARE Center is currently calibrating NIRS spectra to estimate hydrolysable carbohydrates $(\mathrm{HC})$ and other rapidly fermentable carbohydrates, including oligosaccharides, resistant starches and insoluble fibers (NSC-HC). Such data would be useful in evaluating equine nutrition, especially because overload with hydrolysable and rapidly fermented carbohydrates is commonly thought to contribute to several diseases, notably laminitis, colic DOD and, perhaps, one etiologic type of rhabdomyolysis.

The DHIA analysis provided a full mineral profile: $\mathrm{Na}, \mathrm{K}, \mathrm{Ca}, \mathrm{Mg}, \mathrm{P}$, $\mathrm{S}, \mathrm{Fe}, \mathrm{Mn}, \mathrm{Zn}, \mathrm{Cu}, \mathrm{I}$ and Se. Means and ranges $(90 \%$ confidence intervals) were obtained for the 33 forage samples. Comparison with minimum requirements (National Research Council 1989) indicated that $\mathrm{Na}, \mathrm{P}, \mathrm{Zn}, \mathrm{Cu}$ and Se were usually marginal or deficient.

The NRC recomendations may be regarded as mean minimums and, as such, not suitable goals for optimal nutrition (Kronfeld et al. 1994). For example, parabolic responses of 8 variables in growing ponies to four levels of dietary vitamin A indicated an optimal range of 1.5 to 5 times the NRC minimum (Donoghue et al. 1981). This study was reviewed carefully by the NRC, then the minimum was reduced slightly because of a previous clerical error (NRC 1989), thereby illustrating the difference between the minimum and optimum concepts of nutrition.

The (human) recommended daily allowances (RDAs) are derived as the mean minimum requirements plus 2times the standard deviation, thereby covering $98 \%$ of the population (Food and Nutrition Board 1989). When the SD is unknown for a nutrient, the coefficient of variation for energy requirements, $15 \%$, is used. If high performance is desired, the mean plus 3times the CV may be preferable, covering $99.7 \%$ of the population (Kronfeld et al. 1994). Since the SD is unknown for most nutrients, the CV for digestible energy (DE) requirements of growing horses was sought in the literature but not found; instead a CV of $20 \%$ for net energy for growth (Martin-Rosset 1990) has been used. The goal for each mineral has been the mean plus 3times the CV, that is $60 \%$, for the central value and 1 to 5 times the CV, that is 20 to $100 \%$ above the mean, for a tentative optimal range.

Given these goals for dietary minerals and having determined the corresponding means and ranges of forages in our region, we designed a mineral premix to use in a supplement that, when used as $25 \%$ or more of DE intake, would achieve the goal of each mineral falling in its tentative optimal range in the total diet. The design process began with central values, then the effects of the ranges were tested (as in sensitivity analysis commonly used in economics). The mineral premix for each supplement was further modified to allow for the endogenous minerals in the supplement(s). Thus in our pasture studies, mild deficiences of $\mathrm{P}, \mathrm{Zn}, \mathrm{Cu}$ and $S e$ were anticipated in horses fed pasture and hay only but not in those supplemented with concentrate fortified with these minerals in the above manner.
Two farms with several foals and weanlings suffering from DOD were included in the survey. In one, a grain-based supplement designed for grass hay was being fed with alfalfa hay, so the total diet contained excessive $\mathrm{Ca}$; this has been the most common nutritional association with DOD in our experience (Kronfeld et al. 1990). In the other, the grain-based supplement had a 7:1 Zn:Cu ratio, which might result in a conditioned $\mathrm{Cu}$ deficiency, especially because Cu was marginal in the forages.

The survey also brought to attention the overall inaccuracy of ration evaluation of horses on pasture that is attributable to imprecise estimation of pasture consumption. This estimate is obtained by difference, subtracting estimates of DE provided by hay and grain-based supplement from the corresponding mean DE daily intake (NRC 1989). Pasture intake estimated by difference is often negative, even though horses are observed to graze. The NRC DE values appear to relate to horses in stalls, hence underestimate the DE needed for horses grazing. Also, no estimates of variation in DE requirements are given (NRC 1989), so that arbitrary ranges like those for dry matter intake (about $\pm 25 \%$ ) were used for sensitivity analysis. Reports of studies involving ration evaluation of grazing horses rarely illuminate the lack of precision in these estimates of pasture consumption, for example, recent papers on risk factors for colic. The MARE Center is currently developing marker methods for estimating pasture consumption and digestibility in grazing horses.

\section{Phosphorus and selenium}

Blood serum analysis revealed that inorganic $P$ and Se values were lower in weanlings fed only pasture and hay than in those supplemented with a grain-based concentrate fortified with these minerals (Greiwe-Crandell et al. 1992). Weanlings fed only pasture and hay showed no clinical signs of Se deficiency, but a wave of respiratory disease, diagnosed as equine herpesvirus-4 infection, was more rapidly propagated and more clinically severe in this group than in the supplemented group.

\section{Zinc}

Serum zinc concentration declines in most species during stress, including weaning stress. Serum zinc was lower during weaning in foals that had access only to pasture and hay than in those that has access to Zn-fortified supplement (Hoffman et al. 1995).

\section{Vitamin A}

Vitamin A deficiency has long been evident by clinical signs in livestock grazing extensive rangelands during winter or arid periods, and in animals fed conserved feeds. Seasonal fluctuations in vitamin A status has also been demonstrated in mares and weanlings kept on improved pastures by measurements of serum retinol concentration and, better, by the relative dose response (RDR) test (Greiwe-Crandell et al. 1995a). Both serum retinol concentrations and RDR tests of newborn foals have regressed linearly on corresponding data from their dams (Greiwe-Crandell et al. 1996). Winter depletions of vitamin A have not quite been fully compensated by supplementation with 2times the NRC recommendation (Greiwe-Crandell et al. 1995b). In view of these and previous studies (Donoghue et al. 1981; Maenpaa et al. 1988), the optimal ranges for vitamin A may be 2 to 5times the current NRC minimums for growth and reproduction (NRC 1989). 


\section{Form of supplement}

In the above studies, growth rates, body weights and body condition scores of young horses were similar in all dietary groups. Therefore consumption of grain-based supplement, 3-4 kg/day, must have reduced pasture consumption to a similar extent. Thus supplementation of energy, protein and $\mathrm{Ca}$ - the main determinants of growth rate in horses - appeared to be unnecessary. Accordingly, smaller vehicles of minerals and vitamins were considered. Small potent pellets have been used in the last few years as vehicles for $P$, trace elements and vitamins. On one farm plagued by DOD, about $450 \mathrm{~g}$ of pellets were placed in each of 8 buckets for 8 weanlings, and the distribution of consumption may have been uneven. Watching these weanlings, it seemed that one might easily consume twice the amount of pellets as another.

Precise distribution could be obtained by incorporating the minerals and vitamins into a granola bar (100 to $200 \mathrm{~g}$ ), and feeding the bars by hand, one a day to each horse. The fewer the horses, the more this approach would appeal.

More precise than the pellets and less precise than the fortified granola bar is a third delivery system using a larger amount of supplement, 1.5 to $3 \mathrm{~kg}$ twice a day, such as the grain-based concentrate used in our vitamin A depletion-repletion studies (Greiwe-Crandell et al. 1995a, 1995b). This supplement was fed in buckets placed in a large circle in the paddock, one more than the number of horses, so that a timid horse would always have an opportunity to consume its approximate share of the concentrate. Careful observation suggests that the distribution of supplement fed this way has a coefficient of variation of the order of 5 to $10 \%$, almost certainly less than the likely error in estimates of pasture intake by difference.

\section{Starch-and-sugar versus fat-and-fiber}

The typical grain-based concentrate in the USA contains $60 \%$ or more cereal grains and $10 \%$ molasses; it is rich in starch and sugar. Such a concentrate fed as two meals a day might overload hydrolytic digestion and foment fast fermentation, thereby raising the risks of digestive upsets, colic and laminitis. Also, starch and sugar may facilitate growth hormone, and this interaction has been suggested as one of the many factors in DOD (Kronfeld et al. 1990). These possible adverse effects of excessive starch and sugar provided incentive for substitutions with fat and fiber.

In a comparative trial of isoenergetic and isonitrogenous diets (Hoffman et al. 1996), the starch-and-sugar concentrate contained $8 \%$ ADF and 14\% NDF as fed, fairly typical of contemporary concentrates, whereas the fat-and-fiber supplement contained 25\% ADF and $37 \%$ NDF, values in the range for half-hay-half-oats. The fat-and-fiber supplement appeared to help weanlings cope better with seasonal changes in pasture contents of soluble carbohydrates and fibers, such as occur in the spring and after warm rains.

\section{Conclusion}

An optimal dietary supplement for growing horses kept on improved pastures not only needs contents of minerals and vitamins statistically derived to achieve tentative optimal ranges but also needs carefully tailored amounts and proportions of four functionally different types of carbohydrates (hydrolysable, rapidly fermentable, slowly fermentable, and unfermentable). Athough not intended originally, the fat-and-fiber supplement developed in these studies, despite sharing a $14 \mathrm{~J} / \mathrm{kg}$ dry matter energy density with the typical grain-based concentrate, became a complete feed - one that could be fed safely and effectively as the sole sources of nutrients - on the basis of its nutrient composition. The other basis for a complete feed that is accepted in the USA for pet foods - a sole source feeding trial - has not been conducted on growing horses with this fibrous supplement, but similar complete feeds that substitute fat-and-fiber for hydrolyzable and rapidly fermentable carbohydrates have been fed for periods of 12 to 14 weeks to horses used in treadmill experiments at Virginia Tech. A complete feed may be used like a concentrate in combination with forages, except that increasing amounts of a typical grain-based concentrate reach a brink that limits its use, a disadvantage not encountered with a complete feed.

\section{References}

Donoghue, S., Kronfeld, D. S., Berkowitz, S. J. and Copp, R. L. (1981): Vitamin A nutrition of the equine: growth, serum biochemistry and hematology. J. Nutr. 111, 365-374

Food and nutrition board (1989): Reconmmeded Dietary Allowances, 10th edition. National Academy Press, Washington, DC.

Greiwe-Crandell, K. M. Morrow, G. A. and Kronfeld, D. S. (1992): Phosphorus and selenium depletion in Thoroughbred mares and weanlings. Pferdeheilkunde 1-216, 96-98.

Greiwe-Crandell, K. M., Kronfeld, D. S., Gay, L. A. and Sklan, D. (1995a): Seasonal variation in vitamin $A$ status of grazing horses is assessed better by the relative dose response test than by serum retinol concentration. J. Nutr.125, 2711-2716.

Greiwe-Crandell, K. M. Kronfeld, D. S. and Sklan, D. (1995b): Vitamin A and beta-carotene supplementation in horses on different forage systems. Ann. Zootech. 44(708), 308.

Greiwe-Crandell, K. M., Kronfeld, D. S., Gay, L. A., Sklan, D. P. and Harris, A. (1996): Vitamin A status of neonatal foals assessed by serum retinol concentrations and a relative dose response test. Pferdeheilkd. 12, 181-183

Hoffman, R. M., Kronfeld, K. M., Holland, J. L., Crandell, K. M. and Cooper, W. L. (1995): Preweaning diet and stall weaning method influence stress response of foals. J. Anim. Sci. 73, 2922-2930.

Hoffman, R. M., Kronfeld, D. S., Lawrence, L. A., Dascanio, J. J. and Cooper, W. L. (1996): Dietary starch and sugar versus fat and fiber: growth and bone development of foals. Pferdeheilkd. $12,312-316$

Kronfeld, D. S., Meacham, T. N. and Donoghue, S. (1990): Dietary aspects of developmental orthopedic disease in young horses. Vet. Clin. N. Amer. Equine Pract. 6(2), $451-466$.

Kronfeld, D. S., Ferrante, P. L. and Grandjean, D. (1994): Optimal nutrition for athletic performance, with emphasis on fat adaptation in dogs and horses. J. Nutr. 124, 2745S-2753S

Maenpaa, P. H., Pirhonen, A, and Koskiene, E. (1988): Serum profiles of vitamins A, D and $E$ in mares and foals during differencet seasons. J. Anim. Sci. 66, 1418-1423.

Martin-Rosset, W. (1990): L'alimentation des chevaux. INRA Publications, Versailles.

NATIONAL RESEARCH COUNCIL (NCR) (1989): Nutrient requirements of horses, 5th edition. National Academy Press, Washington DC.

Pagan, J. D. (1994): Digestibility trials provide evaluation of feedstuffs. Feedstuff 66 (21), 14-15.

These studies were supported in part by Mr Paul Mellon, Upperville, VA, and by the Waltham Center for Equine Care and Nutrition, Verden, Germany.

\section{S. Kronfeld}

Virginia Tech

Blacksburg, VA 24061-0306

USA. 